\title{
LIPID STATUS IN RACEHORSES FOLLOWING PHYSICAL ACTIVITY OF VARIOUS INTENSITY AND DURATION
}

JOVIĆ S*, STEVANOVIĆ JELKA*, BOROZAN SUNČICA*, DIMITRIJEVIĆ B*, POPOVIĆ TAMARA** and BLAGOJEVIĆ $M^{*}$

\footnotetext{
*University of Belgrade, Faculty of Veterinary Medicine, Serbia

**Institute for Medical Research, Laboratory for Nutrition and Metabolism, Belgrade, Serbia
}

$$
\text { (Received 6 } 6^{\text {th }} \text { January 2013) }
$$

The aim of this research was to determine the effects of physical activity on the lipid status in racehorses in a gallop race and a fortykilometre endurance ride.

Two groups of healthy 3-5-year-old full-blooded racehorses were assessed. The first one ran a 2 400-m gallop race, which is considered a short-lasting, intense physical activity; lipid status was assessed prior to, and 48 and $72 h$ after the race. The second group ran a fortykilometre endurance ride, which is a long-lasting moderate physical activity; the lipid status was assessed immediately before, soon after and 48, 72, 96, 120 and $144 h$ after finishing the race.

In intense physical activity the parameters of lipid status (total cholesterol, HDL cholesterol, LDL cholesterol, free cholesterol and triglycerides) remained stable at all times assessed in comparison with basal concentrations ( $p>0.05)$.

Following the long-lasting moderate physical activity a slight, although statistically insignificant $(p>0.05)$, increase in the concentrations of total cholesterol, HDL cholesterol, free cholesterol and LDL cholesterol was noticed immediately after the endurance ride in comparison to the values before the ride. By contrast, the concentration of $L D L$ cholesterol increased immediately after the gallop race, which was followed by its significant decrease $(p<0.05)$ 96,120 and $144 \mathrm{~h}$ after the ride in comparison to the values both before and immediately after the ride.

Unlike in the gallop race, immediately after the 40-km endurance ride there was a plummet in triglyceride concentration $(p<0.01)$, but was followed by its statistically significant increase $(p<0.05$ and $p<0.01)$ at all sampling times in comparison to the value on finishing the ride.

In horses which ran the gallop race there was a high positive correlation between the concentrations of total cholesterol, HDL cholesterol and triglycerides before, 72 and $96 \mathrm{~h}$ after the race $(r=$ 0.9278, $p<0.001$ ).

In those which ran the endurance ride a high positive correlation between the concentrations of total cholesterol and HDL cholesterol 
was noticed on finishing the ride $(r=0.7395 p<0.01)$, as well as at all sampling times which followed. In addition, there was a positive correlation between the concentrations of HDL cholesterol and LDL cholesterol $72 h(r=0.6843, p<0.01)$ after the ride.

Aerobic exercise decreases the risk of cardiovascular diseases, partly because it is accompanied by the moderate increase in serum concentration of HDL cholesterol, decrease in total cholesterol, LDL cholesterol and triglycerides, which all result in the improvement in lipid profile in horses which completed the endurance ride.

Key words: endurance ride, gallop race, horses, lipid status

\section{INTRODUCTION}

Among the several races in equestrian sport gallop races and long-distance riding (endurance) are the most popular. Physical activities of various intensity and duration influence the biochemical and metabolic processes in the organism; this also applies to moderate (40-km endurance ride) and intense physical activity (2400-m gallop ride) and lipid status in horses (Votion et al., 2010).

Cholesterol is a significant constituent of cell membranes, which renders its concentration important for their integrity and function. Apart from being absorbed from food in the intestine, it is also synthesised de novo from acetyl-CoA (ingested with food or derived from fatty acids in the adipose tissue, from glycogen - via glucose, or from the carbon of amino acids which result from proteolysis) (Essén-Gustavsson and Jensen-Waern, 2002).

In the transport of cholesterol lipoproteins are engaged. Low-density lipoproteins (LDL) transport cholesterol throughout the organism (Manley et al., 2006), including the bone marrow, where it is involved in the production of young neutrophils and monocytes, and the adrenal medulla, the site of corticosteroid synthesis. The role of high-density lipoproteins (HDL) is to enable the transport of excess cholesterol from various cells to hepatocytes. Thus, the use of cholesterol and phospholipids originating from cell destruction is facilitated for the building of new cell membranes. (Dessi and Batteta, 2004; Maxfield and Wustner, 2002; Li et al., 2012; Assenza et al., 2012). Given that free cholesterol is toxic to cell membranes, the whole quantity of excess intracellular cholesterol which cannot be transported outside the cell must undergo esterification by lecithin-cholesterol acyl-transferase (LCAT) into cholesteryl ester (Dessi and Batteta, 2004; Maxfield and Wustner, 2002). The resulting esters can be deposited in various tissues and cells, especially in macrophages (Navab et al., 2001). As a result of the deposition of esterified cholesterol macrophages gain a "foamy" appearance and, consequently, gradually lose their phagocytic power (Dessi and Batteta, 2004; Maxfield and Wustner, 2002). This is the reason why, under basal conditions, HDL have anti-inflammatory properties. These lipoproteins take over the excess of cholesterol from disintegrated cells preventing macrophages from taking it over and transform into foam cells (Navab et al., 2001; Van Lenten et al., 2001). 
During the inflammatory response and the acute-phase reaction (posttraumatic tissue damage) HDL particles lose protective enzymes paraoxonases and the thrombocyte-activating factor the hydrolases, and simultaneously the content of acute-phase proteins increases noticeably (serum amyloid $A$ and ceruloplasmin) (Scoppetta et al., 2012). These result in a general decrease in their antiatherogenic characteristics. This happens because HDL plays a role in the protection of LDL molecules from oxidative modification and the latter induce the cells of artery walls to produce proinflammatory molecules. This anti-inflammatory capacity of HDL occurs thanks to the so-called ENIKSME system, which is attached to these lipoproteins. In addition, this change in HDL molecules may lead to the increase in monocyte/macrophage influx into the arterial walls and the development of predisposition to atherosclerosis (Van Lenten et al., 2002).

Reactive oxygen species which are synthesised during increased physical activity are potent inductors of oxidative damage in cell molecules and peroxidation of membrane lipids (Meydani et al., 1993; Clarkson and Thompson, 2000; Chevion et al., 2003; Lamprecht and Williams, 2012).

\section{MATERIAL AND METHODS}

\section{Animals and blood sampling}

The research was conducted on two groups of clinically healthy 3-5-year old male whole-blooded horses in the Republic of Serbia. The first one comprised 12 racehorses which ran a 2400-m gallop race. The horses belonged to private owners and were kept in stables at the Belgrade racecourse. The second group comprised 13 racehorses which ran the $40-\mathrm{km}$ endurance ride. Some of these belonged to private owners whilst the others were state property. These animals were kept in the stables of the Belgrade or Pančevo racecourse.

All blood samples were taken from the jugular vein without adding any anticoagulant, from gallopers before, and 48 and $72 \mathrm{~h}$ after the race, and from those who ran the endurance ride immediately before and after the race, as well as $48,72,96,120$ and $144 \mathrm{~h}$ after the completion of the ride.

Serum was separated from the blood which coagulated spontaneously at room temperature, centrifuged at $3000 \mathrm{rpm}$ for 10 minutes, frozen and kept at $-20^{\circ} \mathrm{C}$ until analysed.

\section{Biochemical analysis}

The concentrations of total, HDL and LDL cholesterol, and triglycerides in the blood serum were determined with enzymatic methods (test package made by Bioanalytica, BioSystem), with an automatic biochemistry analyser (Bayer Opera). The concentration of free cholesterol in the serum was calculated according to the data on the total, LDL and HDL cholesterol.

\section{Statistical analysis}

Statistical analysis of the results was made with GraphPad Prism 5. The testing of statistical significance and the evaluation of the hypothesis were 
performed with ANOVA (Tukey test and Dunnett test) and T-test. The minimum level of statistical significance was set at $p<0.05$.

The correlation between the parameters tested was examined according to Person's correlation coefficient ( $r$ ), the regression line (Fy) and testing the significance of correlation coefficient and regression.

\section{RESULTS}

In order to determine whether physical activity may influence the lipid status in horses after a 2400-m gallop ride and a 40-km endurance ride, the concentrations of total, HDL, LDL and free cholesterol, and triglycerides were measured.

\section{Concentrations of total cholesterol}

The results of the analysis of total cholesterol in horses after the gallop race and endurance ride are on display in Table 1.

Table 1. Results of total cholesterol concentrations ( $\mathrm{mmol} / \mathrm{L}$ ) in blood serum of horses which ran the 2400-m gallop race and $40-\mathrm{km}$ endurance ride

\begin{tabular}{|l|c|c|c|}
\hline Sampling time & $\bar{X} \pm \mathrm{SD}(\mathrm{mmol} / \mathrm{L})$ & $\min$ & $\max$ \\
\hline \hline \multicolumn{4}{|c|}{ Gallop race } \\
\hline before race & $2.25 \pm 0.37$ & 1.51 & 2.70 \\
\hline $72 \mathrm{~h}$ after the race & $2.53 \pm 0,40$ & 1,64 & 3.10 \\
\hline $96 \mathrm{~h}$ after the race & $2.44 \pm 0.45$ & 1.49 & 2.90 \\
\hline \multicolumn{4}{|c|}{ Endurance ride } \\
\hline before ride & $2.02 \pm 0.38$ & 1.35 & 2.78 \\
\hline immediately after the ride & $2.15 \pm 0.42$ & 1.50 & 2.71 \\
\hline $48 \mathrm{~h}$ after the ride & $2.02 \pm 0.38$ & 1.39 & 2.69 \\
\hline $72 \mathrm{~h}$ after the ride & $1.99 \pm 0.43$ & 1.22 & 2.75 \\
\hline $96 \mathrm{~h}$ after the ride & $1.86 \pm 0.37$ & 1.36 & 2.52 \\
\hline $120 \mathrm{~h}$ after the ride & $1.92 \pm 0.30$ & 1.54 & 2.47 \\
\hline $144 \mathrm{~h}$ after the ride & $1.90 \pm 0.33$ & 1.28 & 2.51 \\
\hline
\end{tabular}

Data: means \pm SD

The concentrations of total cholesterol in the blood serum of horses which ran the gallop race remained stable at all sampling times $(p>0.05)$.

By contrast, in horses which ran the endurance ride the concentrations of total cholesterol increased immediately after the completion of physical activity, which was followed by a gradual, although insignificant $(p>0.05)$ decrease at all times assessed. 
Acta Veterinaria (Beograd), Vol. 63, No. 2-3, 211-226, 2013.

\section{Concentrations of HDL cholesterol}

The results of the analysis of HDL cholesterol levels in horses after the gallop race and endurance ride are shown in Table 2.

Table 2. Results of HDL cholesterol concentrations ( $\mathrm{mmol} / \mathrm{L}$ ) in blood serum of horses which ran the $2400-\mathrm{m}$ gallop race and $40-\mathrm{km}$ endurance ride

\begin{tabular}{|l|c|c|c|}
\hline Sampling time & $\bar{X} \pm$ SD (mmol/L) & $\min$ & max \\
\hline \hline \multicolumn{4}{|c|}{ Gallop race } \\
\hline before race & $1.30 \pm 0.20$ & 0.92 & 1.58 \\
\hline $72 \mathrm{~h}$ after the race & $1.42 \pm 0.23$ & 0.98 & 1.78 \\
\hline $96 \mathrm{~h}$ after the race & $1.37 \pm 0.22$ & 0.95 & 1.74 \\
\hline \multicolumn{4}{|c|}{ Endurance ride } \\
\hline before ride & $1.13 \pm 0.16$ & 0.74 & 1.32 \\
\hline immediately after the ride & $1.21 \pm 0.13$ & 0.97 & 1.34 \\
\hline 48 $\mathrm{h}$ after the ride & $1.13 \pm 0.13$ & 0.84 & 1.33 \\
\hline $72 \mathrm{~h}$ after the ride & $1.13 \pm 0.12$ & 0.96 & 1.34 \\
\hline $96 \mathrm{~h}$ after the ride & $1.11 \pm 0.12$ & 0.89 & 1.33 \\
\hline $120 \mathrm{~h}$ after the ride & $1.12 \pm 0.12$ & 0.92 & 1.24 \\
\hline $144 \mathrm{~h}$ after the ride & $1.13 \pm 0.16$ & 0.74 & 1.32 \\
\hline
\end{tabular}

Data: means \pm SD

The results of the analysis of HDL cholesterol levels in the blood serum of horses which finished the gallop ride revealed that they remained stable at both 72 and $96 \mathrm{~h}$ after completion of the physical activity $(\mathrm{p}>0.05)$.

In contrast, the concentration of HDL cholesterol after the endurance ride rose on crossing the finishing line, but was close to the value which preceded the physical activity $(p>0.05)$.

\section{Concentrations of $L D L$ cholesterol}

Results of the analysis of LDL cholesterol in horses which completed the gallop race and endurance ride are on display in Table 3.

The analysis of the serum concentrations of LDL cholesterol in horses which ran the gallop race suggest that this short-standing activity had no influence on these, in spite of a slight increase $(p>0.05)$ which was noticed 72 and $96 \mathrm{~h}$ after the race.

On the other hand, the levels of LDL cholesterol in horses exposed to longlasting physical activity decreased significantly 96, 120 and $144 \mathrm{~h}$ after the endurance ride in comparison to those before and immediately after the physical activity $(p<0.05)$. 
Table 3. Results of LDL cholesterol concentrations ( $\mathrm{mmol} / \mathrm{L}$ ) in blood serum of horses which ran the $2400-\mathrm{m}$ gallop race and $40-\mathrm{km}$ endurance ride

\begin{tabular}{|l|c|c|c|}
\hline Sampling time & $\bar{X} \pm$ SD (mmol/L) & min & max \\
\hline \hline \multicolumn{4}{|c|}{ Gallop race } \\
\hline before race & $0.67 \pm 0.13$ & 0.50 & 0.96 \\
\hline $72 \mathrm{~h}$ after the race & $0.81 \pm 0.20$ & 0.48 & 1.19 \\
\hline $96 \mathrm{~h}$ after the race & $0.75 \pm 0.24$ & 0.43 & 1.25 \\
\hline \multicolumn{4}{|c|}{ Endurance ride } \\
\hline before ride & $0.91 \pm 0.22$ & 0.60 & 1.36 \\
\hline immediately after the ride & $0.96 \pm 0.30$ & 0.50 & 1.34 \\
\hline $48 \mathrm{~h}$ after the ride & $0.80 \pm 0.30$ & 0.35 & 1.45 \\
\hline $72 \mathrm{~h}$ after the ride & $0.80 \pm 0.34$ & 0.16 & 1.38 \\
\hline $96 \mathrm{~h}$ after the ride & $0.66 \pm 0.28$ & 0.17 & 1.13 \\
\hline $120 \mathrm{~h}$ after the ride & $0.70 \pm 0.23$ & 0.32 & 1.13 \\
\hline $144 \mathrm{~h}$ after the ride & $0.70 \pm 0.22$ & 0.41 & 1.16 \\
\hline
\end{tabular}

Data: means \pm SD

\section{Concentrations of free cholesterol}

Results of the analysis of free cholesterol in horses which completed the gallop race and endurance ride are given in Table 4.

Table 4. Results of free cholesterol concentrations $(\mathrm{mmol} / \mathrm{L})$ in blood serum of horses which ran the $2400-\mathrm{m}$ gallop race and $40-\mathrm{km}$ endurance ride

\begin{tabular}{|l|c|c|c|}
\hline Sampling time & $\bar{X} \pm$ SD (mmol/L) & min & max \\
\hline \hline \multicolumn{4}{|c|}{ Gallop race } \\
\hline before race & $0.95 \pm 0.21$ & 0.59 & 1.28 \\
\hline 72 $\mathrm{h}$ after the race & $1.11 \pm 0.24$ & 0.66 & 1.46 \\
\hline $96 \mathrm{~h}$ after the race & $1.06 \pm 0.27$ & 0.54 & 1.36 \\
\hline \multicolumn{4}{|c|}{ Endurance ride } \\
\hline before ride & $0.89 \pm 0.33$ & 0.16 & 1.46 \\
\hline immediately after the ride & $0.94 \pm 0.34$ & 0.46 & 1.38 \\
\hline 48 $\mathrm{h}$ after the ride & $0.86 \pm 0.31$ & 0.43 & 1.55 \\
\hline $72 \mathrm{~h}$ after the ride & $0.86 \pm 0.34$ & 0.20 & 1.41 \\
\hline $96 \mathrm{~h}$ after the ride & $0.75 \pm 0.29$ & 0.27 & 1.22 \\
\hline $120 \mathrm{~h}$ after the ride & $0.80 \pm 0.21$ & 0.48 & 1.23 \\
\hline $144 \mathrm{~h}$ after the ride & $0.77 \pm 0.24$ & 0.46 & 1.27 \\
\hline
\end{tabular}

Data: means \pm SD 
Acta Veterinaria (Beograd), Vol. 63, No. 2-3, 211-226, 2013.

Although the concentration of free cholesterol increased after the gallop ride, it was of no statistical significance $(p>0.05)$.

Regarding the endurance ride, a slight increase in the concentration of free cholesterol was evident immediately after the race, which was followed by the tendency to decline at all succeeding sampling time points $(p>0.05)$.

\section{Concentrations of total triglycerides}

Results of the analysis of triglycerides in the serum of horses which ran the gallop race and endurance ride are on display in Table 5.

Table 5. Results of triglyceride contents ( $\mathrm{mmol} / \mathrm{L})$ in blood serum of horses which ran the $2400-\mathrm{m}$ gallop race and $40-\mathrm{km}$ endurance ride

\begin{tabular}{|l|c|c|c|}
\hline \multicolumn{1}{|c|}{ Sampling time } & $\bar{X} \pm$ SD (mmol/L) & min & $\max$ \\
\hline \hline \multicolumn{4}{|c|}{ Gallop race } \\
\hline before race & $0.31 \pm 0.19$ & 0.08 & 0.67 \\
\hline 72 $\mathrm{h}$ after the race & $0.30 \pm 0.14$ & 0.09 & 0.51 \\
\hline 96 $\mathrm{h}$ after the race & $0.35 \pm 0.19$ & 0.06 & 0.63 \\
\hline \multicolumn{4}{|c|}{ Endurance ride } \\
\hline before ride & $0.16 \pm 0.05$ & 0.08 & 0.24 \\
\hline immediately after the ride & $0.10 \pm 0.03$ & 0.04 & 0.15 \\
\hline 48 $\mathrm{h}$ after the ride & $0.17 \pm 0.07$ & 0.08 & 0.30 \\
\hline $72 \mathrm{~h}$ after the ride & $0.14 \pm 0.05$ & 0.06 & 0.22 \\
\hline 96 $\mathrm{h}$ after the ride & $0.16 \pm 0.08$ & 0.06 & 0.31 \\
\hline $120 \mathrm{~h}$ after the ride & $0.14 \pm 0.05$ & 0.04 & 0.24 \\
\hline $144 \mathrm{~h}$ after the ride & $0.18 \pm 0.03$ & 0.09 & 0.36 \\
\hline
\end{tabular}

Data: means \pm SD

It was noticed that $72 \mathrm{~h}$ after the gallop race the concentration of total triglycerides insignificantly declined, but slightly increased in the following $24 \mathrm{~h}$ $(p>0.05)$.

In contrast to those relatively stable concentrations after a short-time physical activity, immediately after the endurance ride the concentrations of total triglycerides plunged $(p<0.01)$. However, at other sampling times the concentrations varied: significant increases in concentrations were noticeable 48 and $144 \mathrm{~h}(\mathrm{p}<0.01)$, as well as 72,96 and $120 \mathrm{~h}(\mathrm{p}<0.05)$ after the ride.

Results of correlation analysis between the parameters of lipid status in horses undergoing short- and long-lasting physical activities are given in Figures 1 and 2. 

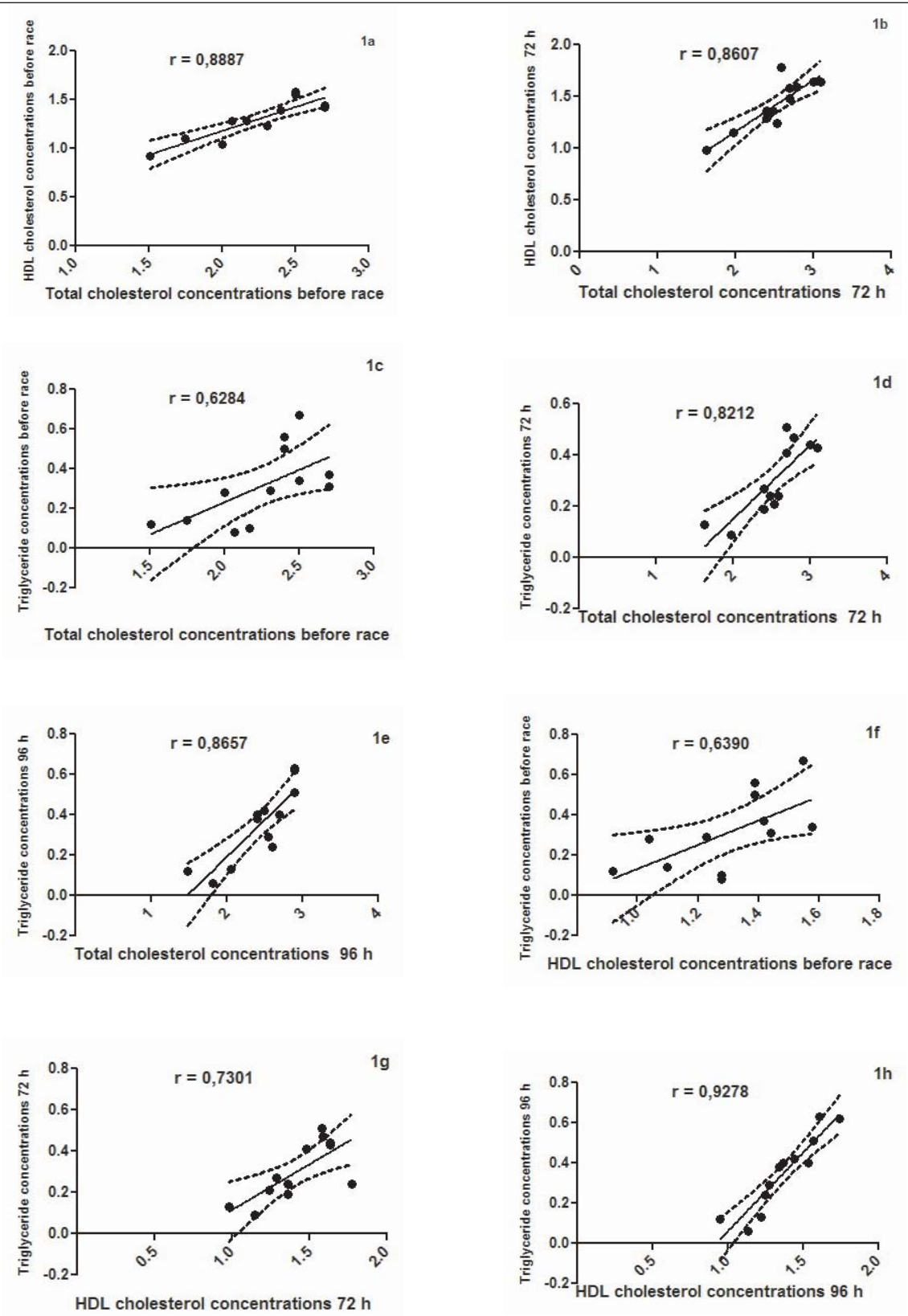

Figure 1. Correlations between parameters of lipid status in horses which ran a gallop race 
Acta Veterinaria (Beograd), Vol. 63, No. 2-3, 211-226, 2013.

Jović $S$ et al.: Lipid status in racehorses following

physical activity of various intensity and duration

In horses running the gallop race correlation analysis between the assessed parameters of lipid status revealed a positive correlation between the total and HDL cholesterol concentrations before $(r=0.8887, p<0.001)$ and $72 \mathrm{~h}$ after the race $(r=0.8607, p<0.001)$, as well as with triglyceride concentrations before $(r=$ $0.6284, p<0.05), 72 \mathrm{~h}(\mathrm{r}=0.8212, \mathrm{p}<0.01)$ and $96 \mathrm{~h}$ after the race $(r=0.8657$, $\mathrm{p}<0.001)$. In addition, there was a positive correlation between HDL cholesterol and triglyceride concentrations before the race $(r=0.6390, p<0.05)$, as well as 72 $h(r=0.7301, p<0.01)$ and $96 \mathrm{~h}$ after the gallop $(r=0.9278, p<0.001)$.
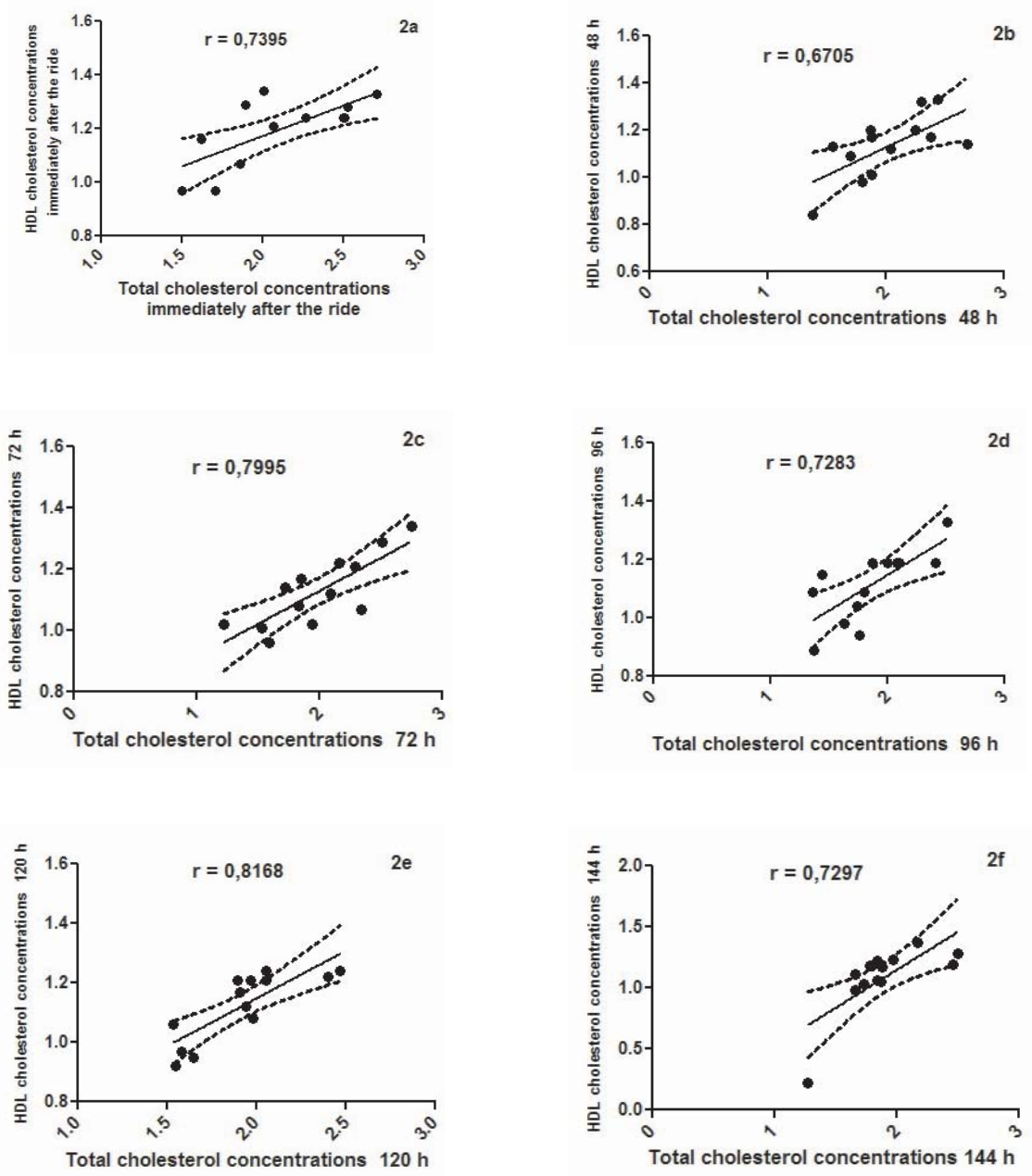

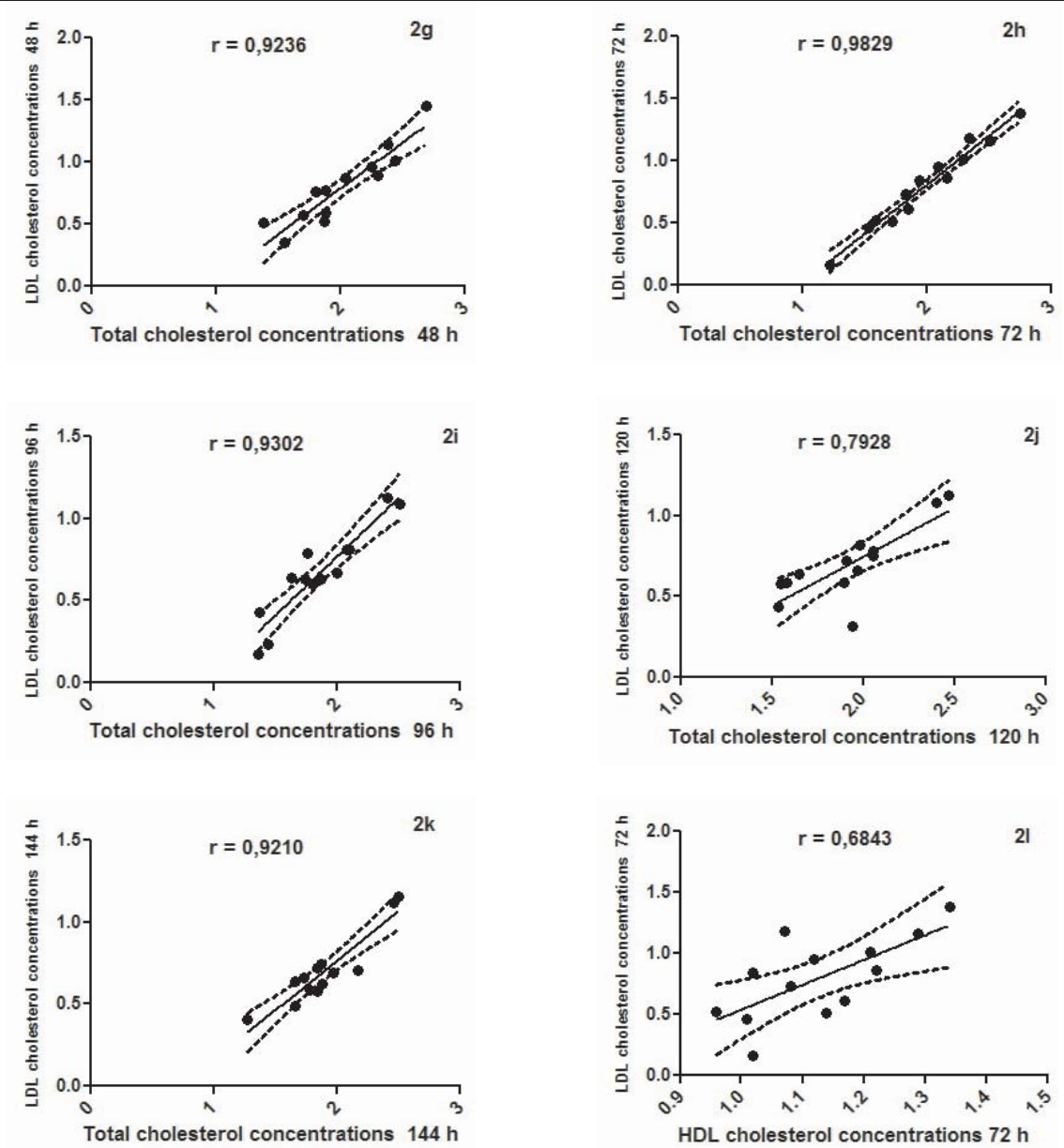

Figure 2. Correlations between parameters of lipid status in horses which ran endurance ride

In horses which completed the endurance ride a positive correlation was discovered between the concentrations of total and $\mathrm{HDL}$ cholesterol immediately after $(r=0.7395, p<0.01)$, and $48 \mathrm{~h}(r=0.6705, p<0.05), 72 \mathrm{~h}(r=0.7995, p<0.01)$, $96 \mathrm{~h}(\mathrm{r}=0.7283, \mathrm{p}<0.01), 120 \mathrm{~h}(\mathrm{r}=0.8168, \mathrm{p}<0.001)$ and $144 \mathrm{~h}(\mathrm{r}=0.7297$, $\mathrm{p}<0.01)$ after the completion of the ride. In addition, these data correlated with LDL cholesterol concentrations $48 \mathrm{~h}(\mathrm{r}=0.9236, \mathrm{p}<0,001), 72 \mathrm{~h}(\mathrm{r}=0.9829$, $p<0.001), 96 \mathrm{~h}(\mathrm{r}=0.9302, \mathrm{p}<0.001), 120 \mathrm{~h}(\mathrm{r}=0.7928, \mathrm{p}<0.001)$ and $144 \mathrm{~h}(\mathrm{r}=$ $0.9210, p<0.001)$ after the ride. Moreover, there was a positive correlation between the concentrations of HDL cholesterol and LDL cholesterol $72 \mathrm{~h}(\mathrm{r}=$ $0.6843, p<0.01$ ) after long-lasting physical activity. 
Acta Veterinaria (Beograd), Vol. 63, No. 2-3, 211-226, 2013.

\section{DISCUSSION}

Many authors assessed the link between regular physical training and the concentrations of blood lipids and lipoproteins in humans. The data suggest that moderate exercise may influence favourably the lipid concentration, although the effects may not be visible until a certain threshold is reached (Haskell, 1984; Durstine et al., 2001; Leon and Sanchez, 2001; Kodama et al., 2007). Evidently, oxidative stress induces changes in the behaviour of cholesterol (Durstine et al., 2001; 2002; Aguilo et al., 2005). Thus, during trainings, when there is a sudden release of energy, the concentrations of HDL cholesterol (HDL-C) rise up to 2-3 $\mathrm{mg} / \mathrm{dL}$, but the concentrations of triglycerides (TG) decrease to $8-20 \mathrm{mg} / \mathrm{dL}$. Larger differences in HDL-C concentrations may arise if the intensity of the exercise increases. However, rarely does physical activity change the total (TC) and LDL cholesterol levels, unless there is a reduction in fat intake and/or a weight loss as a consequence of physical training (Durstine et al., 2001; Votion et al., 2010). After exercise with high energy input (1200-2200 kcal/week) the concentration of HDL-C rises, and the TG, TC and LDL-C decline. With the exception of TG, the frequency and degree of these most common changes in lipid concentrations are similar in both sexes. Aerobic exercise is definitely considered to lessen the risk of developing cardiovascular diseases, partly because of the accompanying moderate increase in serum HDL-C concentration (Kodama et al., 2007), and less frequent reduction in TC, LDL-C and TG concentrations, which all together result in the improvement of the blood lipid profile (Leon and Sanchez, 2001). The increase in the concentration of HDL-C in exhausting exercise results from the rise in the $\mathrm{HDL}_{2}$, a subfraction of lower density, whilst the concentrations of both lipid and protein components rise (Haskell., 1984). These positive effects of regular moderate exercise influence blood lipids and accumulate over time (Durstine et al., 2001; 2002; Kodama et al., 2007).

Our research revealed that in intense physical exercise the parameters of lipid status in gallopers (total cholesterol, HDL cholesterol, free cholesterol and LDL cholesterol) remain stable at all sampling times, although 72 and $96 \mathrm{~h}$ after the race there is a slight increase in these in comparison to the period before the race $(p>0.05)$. Moreover, minor variations in triglyceride concentrations were observed: $72 \mathrm{~h}$ after the race they decreased slightly, but in another $24 \mathrm{~h}$ rose in comparison to the basal concentrations $(p>0.05)$. These results cannot be compared to the data provided by other authors, despite of their accordance with the general notion that exercise leads to minimal effects on total and LDL cholesterol (Durstine et al., 2001; Leon and Sanchez, 2001) and negligible changes in HDL cholesterol in humans (Leon and Sanchez, 2001; Li et al., 2012).

The available literature data mainly refer to humans and are very variable, probably because different physical exercises were studied. For example, Aguilo et al. (2005) state that due to oxidative stress, in exhausting exercise (a 171-km mountain cycling) there is an increase in TG and VLDL cholesterol concentrations in the following $3 \mathrm{~h}$, whilst the total plasma cholesterol, HDL-C and LDL-C remain unchanged. Other authors support the idea that alongside with the increase in the 
intensity and duration of the workout there is a significant rise in the blood concentrations of total and LDL cholesterol, triglycerides and HDL lipoproteins (Northoff and Berg, 1991; Williams, 1996; Durstine et al., 2001; Leon and Sanchez, 2001; Leon et al., 2002; Essén-Gustavsson and Jensen-Waern, 2002; Li et al., 2012; Assenza et al., 2012). However, immediately after an extremely exhausting race (spartathlon) the concentrations of almost all lipids in human blood decrease to minimum and remain so in the following $48 \mathrm{~h}$. The only exception immediately after the race is HDL, which is moderately increased but returns to physiological values within 48 hours (Margeli et al., 2005; Kodama et al., $2007)$. In the current research a slight, insignificant $(p>0.05)$ increase in the concentrations of total, HDL, free and LDL cholesterol was noticed immediately after the $40-\mathrm{km}$ endurance ride, a long-lasting moderate physical exercise, in comparison with the values before the ride. The rise in HDL cholesterol concentration was not unexpected due to lung haemorrhages and increased destruction of muscle cells and erythrocytes, which occur during the race (Pyne, 1994; Uhlar and Whitehead, 1999; Kisilevsky and Tam, 2002; Tam et al., 2002; Dessi et al., 2004); through these lipoproteins the freed cholesterol is involved into new biochemical processes. The total and HDL cholesterol had a decreasing tendency, approaching the values before the ride, which began $72 \mathrm{~h}$ after its completion $(p>0.05)$. By contrast, the concentration of LDL cholesterol increased on finishing the race and significantly decreased afterwards, 96, 120 and $144 \mathrm{~h}$ later, in comparison to the values which preceded or were measured immediately after the ride $(p<0.05)$. These results are incomparable to corresponding data published by other authors, but are in accordance with the results reported by Margeli et al. (2005), who claim that on finishing an extremely exhausting race (spartathlon) the concentrations of the majority of lipids in human blood decrease to minimum values and remain so for the following $48 \mathrm{~h}$; only the level of HDL remain moderately increased on finishing the race, but it also returns into the physiological range within $48 \mathrm{~h}$.

In contrast with the gallop race, which did not influence significantly the concentrations of triglycerides, on completion the $40-\mathrm{km}$ endurance ride a plunge in their concentration was noticed $(p<0.01)$, which was followed by significant increases at all succeeding time points $(p<0.05$ and $p<0.01)$. This cannot be compared with previous findings in horses, but corresponds to the results which showed that, due to oxidative stress, in humans taking exhausting exercise the triglyceride concentrations rise and remain elevated in the following 3-hours time (Aguilo et al., 2005); on the other hand it is conflicting with the statement that at the end of an extremely long walk the triglyceride concentration diminishes to minimum values and remain low for $48 \mathrm{~h}$ (Margeli et al., 2005).

Undoubtedly, during intense physical activity some muscle cells are damaged and their membranes undergo degradation to cholesterol and phospholipids (Pyne, 1994; Dessi and Batteta, 2004). Given that free cholesterol is toxic to healthy membranes, its whole intracellular excess is taken over by LDL and is transported to the cells which need it (for example, bone marrow cells, the site where it is used for the synthesis of new blood cell membranes, or to the adrenal medulla, where the synthesis of steroid hormones takes place). Thus, the 
incorporation of cholesterol and phospholipids into new cell membranes accelerates their use whether for phagocytes or for damaged tissue cells. Fast recycling of the cholesterol from the membranes of damaged cells into new young cells diminished the loss of muscle mass (Manley et al., 2006).

The concentration of total triglycerides in horses which ran the 2400-m gallop race is in positive correlation with the ones of total and HDL cholesterol both prior to and 72 and $96 \mathrm{~h}$ after the race. In addition, the concentration of total cholesterol correlates positively with the level of HDL cholesterol before and $72 \mathrm{~h}$ after the race.

In horses which ran the $40-\mathrm{km}$ endurance ride the concentrations of total cholesterol correlate positively with the ones of HDL cholesterol on completion of the race, 48, 72, 96, 120 and $144 \mathrm{~h}$ after that, and the concentrations of LDL cholesterol at all sampling times, with the exception of those measured immediately before and after the race. In addition to this, there is a positive correlation between HDL and LDL cholesterol concentrations 72 hours after the ride.

In conclusion, given that in horse races pulmonal haemorrhages and increased destruction of skeletal muscles occur, in the current work it has been proved that in horses the blood concentration of HDL lipoproteins increases, because they enable the transport of excess cholesterol, which is not needed in the cells, as well as the reduction of total, LDL cholesterol and triglycerides, which all result in increased lipid mobilisation.

\section{ACKNOWLEDGEMENTS:}

This study was supported by the Ministry of Education, Science and Technological Development of the Republic of Serbia (Project No. 173034).

Adress for correspondence:

Slavoljub Jović, MSc, PhD

Department of Physiology and Biochemistry

Faculty of veterinary medicine, University of Belgrade

Bulevar oslobođenja 18

11000 Belgrade, Serbia

E-mail: romanov@vet.bg.ac.rs

\section{REFERENCES}

1. Aguilo A, Tauler P, Fuentespina E, Tur J, Cordova A, Pons A, 2005, Antioxidant response to oxidative stress induced by exhaustive exercise, Physiol Behav, 84, 1-7.

2. Assenza A, Tosto F, Piccione G, Fazio F, Nery J, Valle E et al., 2012, Lipid utilization pathways induced by early training in Standardbred trotters and Thoroughbreds, J Equine Vet Sci, 32, 704-10.

3. Chevion S, Moran DS, Heled Y, Shani Y, Regev G, Abbou B et al., 2003, Plasma antioxidant status and cell injury after severe physical exercise, Contributed by Earl R Stadtman February 24.

4. Clarkson PM, Thompson HS, 2000, Antioxidants: What role do they play in physical activity and health? Am J Clin Nutr, 72, 637-46.

5. Dessi S, Batteta B, 2004, Intracellular cholesterol homeostasis: old and new players, In: Pani A, Dessi S, editors, Cell growth and cholesterol esters, New York: Kluwer Academic/ Plenum Publishers, 1-12.

6. Durstine JL, Grandjean PW, Cox CA, Thompson PD, 2002, Lipids, lipoproteins, and exercise, $J$ Cardiopulm Rehabil, 22, 6, 385-98. 
7. Durstine JL, Grandjean PW, Davis PG, Ferguson MA, Alderson NL, DuBose KD, 2001, Blood lipid and lipoprotein adaptations to exercise: a quantitative analysis, Sports Med, 31, 15, 1033-62.

8. Essén-Gustavsson B, Jensen-Waern M, 2002, Effect of an endurance race on muscle amino acids, pro- and macroglycogen and triglycerides, Equine Vet J Suppl, 34, 209-13.

9. Haskell WL, 1984, The influence of exercise on the concentrations of trygliceride and cholesterol in human plasma, Exerc Sport Sci Rev, 12, 205-44.

10. Kisilevsky R, Tam SP, 2002, Acute phase serum amyloid A, cholesterol metabolism, and cardiovascular disease, Pediatr Pathol Mol Med, 21, 291-305.

11. Kodama S, Tanaka S, Saito K, Shu M, Sone Y, Onitake $F$ et al., 2007, Effect of Aerobic Exercise Training on Serum Levels of High-Density Lipoprotein Cholesterol: A Meta-analysis, Arch Intern Med, 167, 10, 999-1008.

12. Lamprecht $E D$, Williams $C A, 2012$, Biomarkers of antioxidant status, inflammation, and cartilage metabolism are affected by acute intense exercise but not superoxide dismutase supplementation in horses, Oxid Med Cell Longev, 920-32.

13. Leon AS, Gaskill SE, Rice T, Bergeron J, Gagnon J, Rao DC et al., 2002, Variability in the response of HDL cholesterol to exercise training in the HERITAGE Family Study, Int J Sports Med, 23, 1, 1-9.

14. Leon AS, Sanchez OA, 2001, Response of blood lipids to exercise training alone or combined with dietary intervention, Med Sci Sport Exer, 33, 6, 502-15.

15. Li G, Lee P, Mori N, Yamamoto I, Arai T, 2012, Long term intensive exercise training leads to a higher plasma malate/lactate dehydrogenase (M/L) ratio and increased level of lipid mobilization in horses, Vet Res Commun, 36, 149-55.

16. Manley PN, Ancsin JB, Kisilevsky R, 2006, Rapid recycling of cholesterol: The joint biologic role of C-reactive protein and serum amyloid A, Med Hypotheses, 66, 784-92.

17. Margeli A, Skenderi K, Tsironi MA, Hantzi E, Matalas AL, Vrettou C et al., 2005, Dramatic Elevations of Interleukin-6 and Acute-Phase Reactants in Athletes Participating in the Ultradistance Foot Race Spartathlon: Severe Systemic Inflammation and Lipid and Lipoprotein Changes in Protracted Exercise, J Clin Endocr Metab, 90, 7, 3914-8.

18. Maxfield FR, Wustner D, 2002, Intracellular cholesterol transport, J Clin Invest, 110, 891-8.

19. Meydani M, Evans WJ, Handelman G, Biddle L, Fielding RA, Meydani SN et al., 1993, Protective effect of vitamin $E$ on exercise-induced oxidative damage in young and older adults, $A m J$ Physiol, 264, 992-8.

20. Navab M, Berliner JA, Subbanagounder G, Hama S, Lusis AJ, Castellani LW et al., 2001, HDL and the inflammatory response induced by LDL-derived oxidized phospholipids, Arterioscl Throm Vas, 21, 481-8.

21. Northoff $H$, Berg A, 1991, Immunologic mediators as parameters of the reaction to strenuous exercise, Int J Sports Med, 12, 9-15.

22. Pyne DB, 1994, Exercise-induced muscle demage and inflamation: a review, Aust J Sci Med Sport, 26, 3-4, 49-58.

23. Scoppetta F, Tartaglia M, Renzone G, AvelliniL, Gaiti A, Scaloni A et al., 2012, Plasma protein changes in horse after prolonged physical exercise: A proteomic study, J proteomics, 75, 4494504.

24. Tam S P, Flexman A, Hulme J, Kisilevsky R, 2002, Promoting export of macrophage cholesterol: the physiological role of a major acute-phase protein, serum amyloid A 2.1, J Lipid Res, 43, 141020.

25. Uhlar CM, Whitehead AS, 1999, Serum amyloid A, the major vertebrate acute-phase reactant, Eur J Biochem, 265, 2, 501-23.

26. Van Lenten BJ, Navab M, Shih D, Fogelman AM, Lusis AJ, 2001, The role of high-density lipoproteins in oxidation and inflammation, Trends Cardiovas Med, 11, 155-61.

27. Van Lenten BJ, Wagner AC, Anantharamaiah GM, Garber DW, Fishbein MC, Adhikary L et al., 2002, Influenza infection promotes macrophage traffic into arteries of mice that is prevented by $\mathrm{D}-4 \mathrm{~F}$, an apolipoprotein A-I mimetic peptide, Circulation, 106, 1127-32. 
Acta Veterinaria (Beograd), Vol. 63, No. 2-3, 211-226, 2013.

Jović $\mathrm{S}$ et al.: Lipid status in racehorses following

physical activity of various intensity and duration

28. Votion DM, Fraipont A, Goachet AG, Robert C, van Erck E, Amory $H$ et al., 2010, Alterations in mitochondrial respiratory function in response to endurance training and endurance racing, Equine Vet J Suppl, 38, 268-74.

29. Williams PT, 1996, High-density lipoprotein cholesterol and other risk factors for coronary heart disease in female runners, New Engl J Med, 334, 1298-303.

\title{
LIPIDNI STATUS TRKAČKIH KONJA NAKON FIZIČKOG OPTEREĆENJA RAZLIČITOG INTENZITETA I TRAJANJA
}

\author{
JOVIĆ S, STEVANOVIĆ JELKA, BOROZAN SUNČICA, DIMITRIJEVIĆ B, \\ POPOVIĆ TAMARA i BLAGOJEVIĆ M
}

\section{SADRŽAJ}

Cilj ovog rada je bio utvrdjivanje efekata fizičkog opterećenja različitog intenziteta tokom galopske trke i endjurans trke, na lipidni status trkačkih konja.

$U$ ispitivanju su učestvovali zdravi punokrvni trkački konji, starosti 3-5 godina, podeljeni u dve grupe. Prva grupa trkačkih konja podvrgnuta je kratkotrajnom fizičkom opterećenju visokog intenziteta tokom galopske trke na $2400 \mathrm{~m}$, i lipidni status je određivan pre učešća u trci, 48 h i 72 h posle istrčane trke. Druga grupa trkačkih konja podvrgnuta je prolongiranom fizičkom opterećenju niskog intenziteta tokom endjurans trke na $40 \mathrm{~km}$, a lipidni status je određivan pre učešća $\mathrm{u}$ trci, neposredno posle istrčane trke, $48 \mathrm{~h}, 72 \mathrm{~h}, 96 \mathrm{~h}, 120 \mathrm{~h}$ i $144 \mathrm{~h}$ posle istrčane trke.

Kod fizičkog vežbanja visokog intenziteta parametri lipidnog statusa (ukupni holesterol, HDL-holesterol, LDL-holesterol, slobodni holesterol i trigliceridi) ostaju stabilni u svim ispitivanim vremenskim intervalima u odnosu na bazalne koncentracije $(p>0,05)$.

Nakon dugotrajnog fizičkog vežbanja niskog intenziteta uočen je blagi porast koncentracije ukupnog holesterola, HDL-holesterola, slobodnog holesterola i LDL-holesterola odmah nakon endjurans trke na $40 \mathrm{~km}$ u odnosu na vrednosti pre trke, mada dobijeni rezultati nisu pokazali statističku značajnost $(p>0,05)$.

Nasuprot njima, koncentracija LDL-holesterola se povećala neposredno nakon trke, a potom se statistički značajano smanjivala u uzorcima uzetim $96 \mathrm{~h}$, $120 \mathrm{~h}$ i $144 \mathrm{~h}$ nakon trke u odnosu na vrednost pre trke i neposredno nakon trke $(p<0,05)$.

Za razliku od galopske trke, neposredno nakon endjurans trke na $40 \mathrm{~km}$ došlo je do naglog statistički značajnog pada koncentracije triglicerida $(p<0,01)$, a potom je u svim narednim ispitivanim vremenskim intervalima dokazan njihov statistički značajan porast $(p<0,05$ i $p<0,01)$ u odnosu na vrednosti triglicerida neposredno nakon trke.

Kod galopske trke ustanovljena je medjusobna visoka pozitivna korelacija između koncentracije ukupnog holesterola, koncentracije HDL-holesterola i koncentracije triglicerida pre, $72 \mathrm{~h}$ i $96 \mathrm{~h}$ posle trke $(r=0,9278, \mathrm{p}<0,001)$. 
Kod endjurans trke ustanovljena je medjusobna visoka pozitivna korelacija između koncentracije ukupnog holesterola i HDL-holesterola neposredno nakon trke $(r=0,7395, p<0,01)$, kao i u svim ispitivanim vremenskim intervalima posle endjurans trke. Dokazana je i pozitivna korelacija između koncentracije HDLholesterola i LDL-holesterola $72 \mathrm{~h}(r=0,6843, \mathrm{p}<0,01)$ nakon trke.

Aerobnim vežbanjem se smanjenje rizik od razvoja kardiovaskularnih bolesti, delimično usled pratećeg umerenog povećanja serumske koncentracije HDL-holesterola uz redukciju ukupnog holesterola, LDL-holesterola i triglicerida, što sve zajedno rezultira poboljšanjem lipidnog profila krvi konja koji su trčali endjurans trku. 